\title{
Challenges of Small Businesses in using Digital Platforms for Promoting their Products
}

\author{
Aileen G. Bondoc ${ }^{1}$, Sharon M. Bartolome ${ }^{2}$, Mary Ann B. Gaddi ${ }^{3}$, Tracy Anne I. Katsuta ${ }^{4}$, \\ Janet M. Nerie ${ }^{5}$, Felipe E. Balaria ${ }^{6}$
}

\author{
${ }^{1}$ Registrar's Office Personnel, Nueva Ecija University of Science and Technology, Philippines \\ ${ }^{2}$ Senior Mall Marketing Officer, Robinsons Townville Cabanatuan, Philippines \\ ${ }^{3}$ Senior High School Teacher, Putlod-San Jose National High School, Philippines \\ ${ }^{4}$ Senior Account Executive, Harvest Hotel, Philippines \\ ${ }^{5}$ Lecturer, Nueva Ecija University of Science and Technology, Philippines \\ ${ }^{6}$ Professor, Nueva Ecija University of Science and Technology, Philippines
}

Received: 12 Jun 2021; Received in revised form: 03 Jul 2021; Accepted: 10 Jul 2021; Available online: 19 Jul 2021

\begin{abstract}
Small businesses can expand by adopting the correct digital marketing approaches, tools, and strategies on digital platforms, where there is a greater opportunity for smaller enterprises to advance to the next level. Digital marketing agencies are typically hired by business owners who do not know how to put up digital marketing campaigns on their own [1]. Digital marketing services are in charge of keeping organizations online while working within their budget constraints. Businesses, regardless of their size, should always ensure the promotion of their clients' enterprises in order to maintain continual technological innovation. When innovative technology becomes a mainstay for larger firms, the hurdles for small enterprises grow much more difficult. This study described the business owners' preparedness and knowledge in different digital platforms. Results revealed that only a few business owners know how the digital world works. Most of them were only in the basic skills of their knowledge in the digital platforms. They have inadequate online payment options because of high processing fees, poor internet connection, and limited knowledge on how to use the application. Another challenge for the business owners was competition in Digital World for paid ads versus organic and poor brand credibility.
\end{abstract}

Keywords - Consumers, digital platforms, internet, promotion, small business owners.

\section{INTRODUCTION}

Small businesses played an important role in today's global economy because they were one of the primary contributors to our country's economic progress, particularly in terms of job creation. The majority of small business owners are always seeking fresh ways to bring their brand in front of potential clients. Even before the pandemic, using digital platforms in business is a terrific way to communicate with current clients and recruit new ones in this digital world.

Digital platform marketing has become the most potent method of marketing for small business owners nowadays since it can reach practically everyone, everywhere, at any time. The majority of efforts in digital platform marketing are focused on creating content that attracts attention and motivates readers to share it with their social media networks. Because the majority of people now have social media accounts, social media has become the most accessible forum for everyone [2]. Small business communication has improved, and brand awareness and new product launches have become easier to promote. Furthermore, digital marketing provides a low-cost platform for small enterprises to undertake marketing efforts, as social networking websites allow people to communicate with one another and develop networks.

As it connects small business owners and customers, digital platform sites increase visibility on the internet, which helps advertise products and services. They are also 
excellent for developing social and business networks, as well as exchanging ideas and expertise. Nowadays, customers ha ve the ability to chat about a brand and publish their thoughts on the goods and services on the company's website as well as on social media [3]. As a result, small businesses have little choice but to recognize digital marketing's power and treat it with extra attention and respect. Because social media has such a significant impact on customers' purchasing decisions, every business should make the most of it. By giving your business brand a social media touch, you can not only generate more profit but also connect with new customers better by being open to their suggestions and comments in order to serve them better. It simplifies digital marketing.

Because they can communicate with the right audience and present their unique products and services to potential clients, small business owners have a lot of business growth chances with digital marketing platforms [4]. Digital marketing allows offline firms to reach a broad audience beyond their physical reach, allowing them to abandon traditional advertising in favor of less expensive digital advertising [5]. Small businesses that begin in the digital world recognize the importance of online marketing in today's world. As a result, they should place a greater emphasis on marketing in the digital era, which comes with its own set of obstacles. Unfortunately, most small businesses struggle to build a strong online presence, which is a challenge they can't afford to ignore. The internet world has changed dramatically and continues to change, making small business owners' digital marketing strategies more complex than ever [6]. Since these topics are new, the researchers find relevance in conducting this study that aimed to describe business owners' preparedness, knowledge, and tools used in different digital platforms, the small business and consumers' response to friendly options, the problems encountered by the small business owners on how to convert leads into paying customers and the solutions offered to address the current problems of small business owners to gain the trust of the audience.

\section{METHODOLOGY}

This study used a descriptive research design with researchers' made instrument as the main tool in collecting the data. A total of 350 people were picked as respondents of the study such as business owners, digital marketers, customers as professionals, parents, and students who have knowledge about the usage of digital platforms. Digitized online surveys via google forms and email were used in gathering data from the respondents.

\section{RESULTS AND DISCUSSION} 1. Business owners' preparedness and knowledge in different digital platforms.

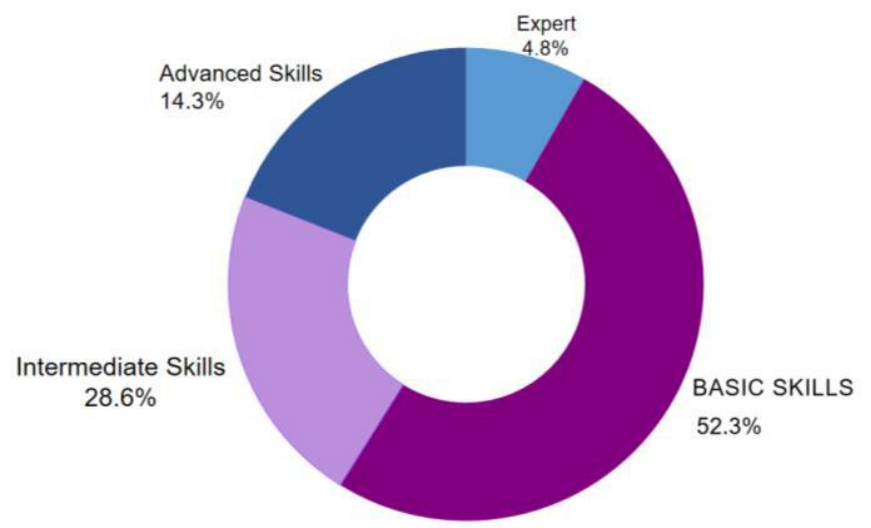

\section{Fig.1. Levels of Skills of Small Business Owners in Using Digital Platforms}

Figure 1 (Pie Chart) presents the levels of skills of small business owners in using digital platforms in promoting their businesses. As to levels of digital skills, $52.3 \%$ of the small business owners have basic knowledge on how to optimize and manage digital platforms. Thus, they know the basic features of their personal accounts on Facebook, Instagram, and YouTube. Based on the survey the researchers found out that only $28.6 \%$ of the Intermediate skills have knowledge in using these business digital platforms, intended to target a specific audience for business campaigns. The 3rd level is the Advanced Skills which garnered $14.3 \%$. These are the business owners whose digital skills have cognition about the power of paid ADs, video editing, content management, and account optimization, and more. Thus, only $4.8 \%$ fall to the Expert Category when it comes to the level of digital skills. Meaning only a few business owners know how the digital world works.

However, these digitized applications may require familiarity in varied situations. Where pieces of training for making videos is a must, in order for small business owners to ensure familiarity with the system. The use of this application quite necessary when having an online business especially you can't hire manpower to manage the digital platforms' business accounts that require conceptualization, content creation, and management, cross-promotion, layout artwork, video editing, search engine optimization down to technical system concerns. Exploring the benefits of mobile technology to SMEs will help business owners hook their customers easily without spending too much on budget. It is also crucial to small business owners to provide easy payment options for their customers especially if potential buyers are of old age and 
have limited access or skills in making an online payment as shown in Figure 2.

\section{Business owners' and consumers'responses to} friendly payment options.

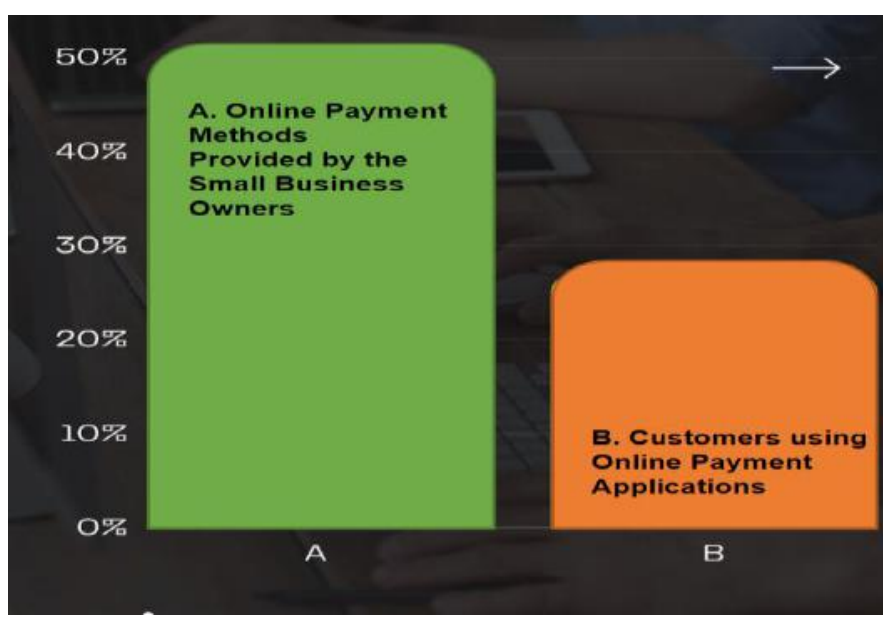

Fig.2. Access to Multi-Channel Payments

Based on our survey about $48 \%$ of small business owners have limited online payment options because of high processing fees, poor internet connection, and having limited knowledge on how to use the application. While $29 \%$ of potential customers are using 1 to 2 apps use for cashless transactions. The rest have no access to the App provided by telecommunications or companies and just do the traditional payment transactions. Switching to an integrated payment platform, business owners can save time and reduce errors by having transaction records updated automatically and in real-time. This also boosts their processing efficiency while allowing the owners to focus more on significant matters for the business growth. Based on our interviews with the respondents having at least two payment channels will help increase the sales of small business owners because of its hassle-free transactions.

\section{Problems encountered by the small business owners on how to convert leads in paying customers.}

The most important challenges small businesses are facing today based on the gathered data are shown in the figure. Our study showed that there are a handful of challenges impacting small businesses in terms of advertising and marketing using digital platforms.

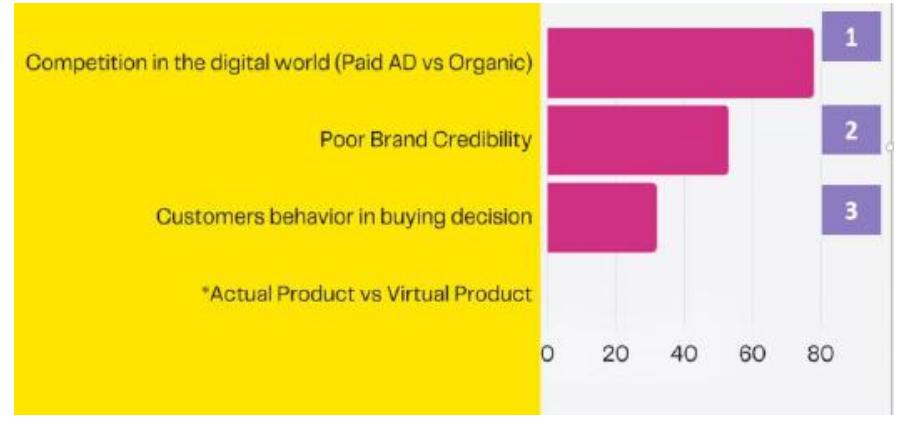

Fig.3: Problems Encountered

Based on this research, competition in the digital world for paid ads versus organic reach ranked as number one on the problems encountered by small businesses. Brand's credibility landed second in our survey. Researchers learned that credibility is important in building a successful online business whether your online business is a spin-off of an already-existing enterprise or a new solely online venture, how customers perceive your small businesses plays a critical role in the business success. Strong brand credibility can help everyone from ecommerce stores to freelancers earn and keep their online customers' trust [8]. Another problem encountered which ranked 3rd was the customers prefer to see, feel touch the actual product before they purchase. There are people who do not like to do online shopping because they prefer to go to the store by themselves and see the actual goods. Mostly, women love to shop a lot and prefer traditional shopping to online shopping. Small business owners may conduct new ways to overcome it by promoting their business online [9].

\section{CONCLUSION AND RECOMMENDATIONS}

The challenges encountered [10] that small business owners face now in using digital platforms are vastly different from those that they faced in the past while using traditional advertising. It's critical to have a shared awareness of the issues that small business owners are currently confronting. Because of the global expansion of the digital economy and society, small business owners must be trained with a variety of digital skills in order for their companies to succeed [11]. Digital platforms are especially crucial currently because of the significant influence they have had on small enterprises. Small business owners must rethink and reorganize their operations, focusing on how to include social media, mobile connection, data analytics, and cloud computing into their business models [12]. Small business owners must integrate digital transformation into all aspects of 
their operations in order to provide value to customers and maintain business continuity. Using digital platforms to market your business provides opportunities for numerous enterprises to reach the crowd in this digital era. Small business owners with strong digital abilities can take advantage of a greater range of opportunities as digital technologies, platforms, and gadgets continue to evolve. Digital platforms are especially crucial currently because of the significant influence they have had on small enterprises. Small company owners with the necessary digital skills can advertise or sell their products online using their smartphones by simply uploading them. It is possible to attend or organize digital platform seminars or training in order to gain a better understanding of how digital platforms work and how they will be optimized. This might be done on a regular basis to keep small business owners informed about current digital technology advances. Small business owners must create appropriate brand messaging material. Make an appealing presentation of it by encouraging target consumers to interact with the brand's message. The proprietor of a small business should never stop learning. They must continue to improve and grow their social media abilities in order to advance and use them in their business to effectively reach out to the community [13]. They put a strong emphasis on developing these skills by enrolling in short courses such as Social Media Management and Digital Marketing, which they can use to create outcomes, understand the true business impact, and improve small business owners' ability to tackle problems. More players (online application payment service providers) are needed to make it easier for small company owners and customers to make payments. The local government tap with the private company's network providers can play a vital role in this project. Online payments are even assisting in the faster delivery of stimulus monies to customers. When it comes to audio or video, some people prefer to listen rather than read. Encourage customers to provide comments. Adding more feedback to the business's product/service could help it improve.

\section{REFERENCES}

[1] The Week Magazine

https://www.theweek.in/news/biz-tech/2020/07/07/how-

digital-marketing-can-help-small-businesses-during-apandemic.html

[2] Journal of Organizational Management, Volume 3, Issue 1, January 2014 Journal homepage: http://www.hgpub.com/index_files/jorm/jorm.html

[3] https://en.wikipedia.org/wiki/Social_media_marketing

[4] The week Magazine https://www.theweek.in/news/biztech/2020/07/07/how-digital-marketing-can-help-small- businesses-during-a-pandemic.html

[5] https://digitalmarketinginstitute.com/blog/why-digitalmarketing-is-important-for-small-business

[6] Nicholas A. Christakis https://www.edge.org/responses/how-is-the-internetchanging-the-way-you-think

[7] MICA, Ahmedabad, India, J. Mack Robinson Emerging Market Retail: Transitioning from a Product-Centric to a Customer-Centric Approach https://www.sciencedirect.com/science/article/abs/pii/S002 2435921000087\#!

[8] Fischer, 1980, Fallow and Steven, 2000): Teaching in a Digital Age https://opentextbc.ca/teachinginadigitalage/chapter/section1-3-the-skills-needed-in-a-digital-age/

[9] Nebojša Vasić1Milorad Kilibarda 2 ,Tanja Kaurin.The Influence of Online Shopping Determinants on Customer Satisfaction in the Serbian Market https://scielo.conicyt.cl/scielo.php?script=sci_arttext\&pid= $\underline{\text { S0718-18762019000200107 }}$

[10] Abelardo, L., Lomboy, M., Lopez, C., Balaria, F., \&Subia,G. (2019). Challenges Encountered by the National High School Teachers in Doing Action Research. International Journal of English, Literature and Social Science (IJELS) Vol-4, Issue-4, Jul - Aug 2019 https://dx.doi.org/10.22161/ijels.4418 ISSN: 2456-7620.

[11] Brian Wong How digital entrepreneurs will help shape the world after the COVID-19 pandemic

[12] Mckinsey\& Company The Next Normal The recovery will be digital https://www.mckinsey.com/

[13] Mina, J.C., Barlis, P.T., Vega, N.C. and Subia, G.S. (2019). Corporate Social Responsibilities of Selected Resorts inCabanatuan City, Nueva Ecija, Philippines. Open AccessLibrary Journal, 6: $\quad$ e 5292. https://doi.org/10.4236/oalib.1105292 